\title{
Perceptions of sister queens: A comparison of printed book dedications to $M$ ary and Elizabeth Tudor
}

\author{
Valerie Schutte \\ Independent Scholar
}

\begin{abstract}
Comparisons of Mary and Elizabeth Tudor, sister queens of England, have become popular in the last decade as scholars have realized the impact of Mary on Elizabeth's queenship. To further that comparison, this essay likens printed book dedications to Mary and Elizabeth before each woman became queen and during their first five (or only five) years as queens. This essay argues that dedications to the Tudor sister queens show that these two women were perceived more commonly than has previously been recognized. By exploring these book dedications, it becomes evident that dedications were central to contemporary perceptions of what authors and translators thought Mary and Elizabeth would be interested in reading and passing along to their subjects along with what dedications thought the sister queens should be reading so as to be persuaded in different directions.

KEYWORDS: Queen Mary I; Queen Elizabeth I; Tudor; book dedications; John Proctor; John Foxe; Laurence Humphrey.

\section{Percepciones de las reinas hermanas: una comparación de dedicatorias a \\ M ary y Elizabeth Tudor en los libros impresos*}

RESUMEN : Las comparaciones entre Mary y Elizabeth Tudor, hermanas y reinas de Inglaterra, se han popularizado en la última década a medida que los investigadores se han dado cuenta del impacto de Mary en el reinado de Elizabeth. Para llevar esa comparación aún más lejos, este artículo equipara las dedicatorias a Mary y a Elizabeth incluidas en libros impresos antes de que se convirtieran en reinas y durante sus primeros cinco años de reinado. El presente trabajo sostiene que

Perceções de rainhas irmãs: uma comparação de dedicatórias a $M$ ary e Elizabeth Tudor em livros impressos ${ }^{* *}$

RESUMO: Mary e Elizabeth Tudor, rainhas irmãs de Inglaterra, tornaram-se populares na última década à medida que os estudiosos têm vindo a entender o impacto de Mary no reinado de Elizabeth. De modo a aprofundar essa comparação, este ensaio confronta dedicatórias a Mary e a Elizabeth em livros impressos antes de cada uma se tornar rainha assim como durante os primeiros cinco anos (ou nos únicos cinco anos) do reinado de cada uma. Este ensaio argumenta que as dedi-
\end{abstract}

\footnotetext{
*Translation into Spanish by Tamara Pérez-Fernández

** Translation into Portuguese by Miguel Ramal hete.
} 
las dedicatorias a las hermanas y reinas Tudor demuestran que estas dos mujeres fueron percibidas de forma más cercana de lo que previamente se había pensado. Con este análisis se hace evidente que estas dedicatorias fueron fundamentales en las percepciones contemporáneas de lo que autores y traductores pensaban que Mary y Elizabeth podrían estar interesadas en leer y en hacer circular entre sus súbditos, así como lo que las dedicatorias pensaban que las reinas hermanas deberían leer para inclinarlas en determinados sentidos.

PALABRAS CLAVE: Mary I; Elizabeth I; Tudor; dedicatorias en libros; John Proctor; John Foxe; Laurence Humphrey. catórias às rainhas irmãs Tudor mostram que estas duas mulheres eram entendidas de uma forma mais próxima do que o que se tem vindo a pensar. Ao explorar estas dedicatórias em livros, torna-se evidente que as dedicatórias ocupavam um lugar central nas perceções contemporâneas daquilo que autores e tradutores achavam que Mary e Elizabeth estariam interessadas em ler e em passar aos seus súbditos, assim como o que as dedicatórias consideravam dever ser lido pelas rainhas irmãs, de modo a serem persuadidas em diferentes direções.

PALAVRAS-CHAVE: Rainha Mary I; Rainha Elizabeth I; dedicatórias de livros; John Proctor; John Foxe; Laurence Humphrey.

I "exhort your grace to the continuance of your godly and vertuous liuing [...] and send your grace as it were an anker [...] least that your grace should (that God forbid) wauer or slide from the Catholike and true faith of God" (Hannapes 1561, C.iiii.v-C.v.r). Thomas Paynell wrote these words to Queen Elizabeth I in 1561, accompanying his translation of $\mathrm{Nicholas} \mathrm{de} \mathrm{Hannapes} \mathrm{The} \mathrm{en} \mathrm{samples}$ of vertue and vice. Paynell's dedication continued to praise Elizabeth's virtuous living as a model for other women. While his dedication to Elizabeth was just one of 183 printed book dedications that she received while she was queen, it is important for its resemblance to the dedications that Elizabeth's sister, Mary, received while she was queen. Paynell dedicated translations not only to Elizabeth and Mary, but also to their father, King Henry VIII (Moore 2011). As with Elizabeth, Paynell's dedications to Mary also advocated for Roman Catholicism while at the same time praised her wisdom and virtue. Superficially, dedications, such as those by Paynell, to Elizabeth and Mary followed similar rhetorical strategies, acknowledged that connection to a royal patron increased the authority of their texts, and offered some type of counsel to their dedicatees. Yet dedications to the sisters are important because they show that dedicators perceived the Tudor queens more similarly than has previously been recognized. 
This essay offers a comparison of the printed book dedications received by Mary and Elizabeth, of which those by Paynell are just a few. Specifically, I will briefly discuss pre-accession dedications to the sisters and focus the majority of the essay on all of the dedications given to Mary while she was queen and those to Elizabeth during the first five years in which she was queen, from November 1558 to 1563. This narrow frame of comparison is useful because during the first (or only) five years of each of their reigns, each queen faced similar challenges of obedience from their subjects, the state of church within England, and suitors and marriage, thereby providing the greatest similarities in purpose of dedicating to the Tudor queens. I will provide an overview of those similarities, such as counsel-giving and religion, as well as explaining one key difference: how dedicators perceived each queen to have influence over statecraft.

Comparisons of Mary and Elizabeth have only recently begun to be undertaken by scholars, and tend to focus on education, imagery, and ceremony, such as their coronation entry processions and how each woman touched for scrofula, but I suggest that book dedications are another area for comparison that have previously been under-utilized (Pollnitz 2015; Mclntosh 2009; Duncan 2011; Hunt and Whitelock 2010; Brogan 2015). Dedication comparison offers information regarding how authors and translators addressed each queen, offered them counsel, used textual imagery for both flattery and condemnation, used their names to increase book sales and influence, and in some cases how these sister queens negotiated with dedicators over patronage.

An examination of book dedications to Mary and Elizabeth also contributes to some of the newest emerging historiography of queenship, women's readership, and book creation. Over the last three decades, several scholars have undertaken to both categorize and explicate the relationships between women, reading, writing, textual reproduction (Hull 1982; Burke 2000; Erler 2002; Hannay 1985; Frye 2010; Goldsmith and Goodman 1995). However, the study of book dedications has only recently been taken seriously, instead of denigrated as praise that might not have reflected actual textual relationships (Wood 2008; Buchtel 2004; 2008; Baranda Leturio 2011; Guardiola-Griffiths 2011). Both Julia Crawford and Helen Smith have used book dedications to show that early modern books were 
collaborative efforts, and therefore consisted of more gendered interaction than has previously been recognized (Crawford 2014; Smith 2012). More specific to this essay, several recent studies have emerged that explicate dedications to Queen Mary I, yet they have focused on dedications to other royal women that mention Mary, a comparison of pre-accession dedications to Mary and Elizabeth, and a bibliographic analysis of all manuscript and printed book dedications to Mary (Schutte 2015; 2016; forthc.). This essay is in conversation with these studies, but adds to them by offering a comparison of specific elements of dedications to Mary and Elizabeth, such as counsel, to show that book dedications are overlooked sources that explain the process whereby a specific text was chosen for a specific dedicatee while at the same time offers insight into perceptions of that dedicatee. This essay contributes to furthering the understanding of ways in which Mary and Elizabeth were considered alike and how images of both women were proliferated by others, often without their knowledge or permission.

\section{D edications to the $Q$ ueens}

Before Mary and Elizabeth Tudor became queens of England, they each received a variety of printed book and manuscript dedications, as befitting their positions as daughters of and sisters to a king. Specifically, Mary received nineteen dedications and Elizabeth received seven, most likely because Mary was seventeen years older than Elizabeth and became queen at age 37 while Elizabeth inherited the throne at age 25 (Schutte 2015, 33-48; forthc.). Books on religion made up the majority of texts dedicated to Mary and Elizabeth, with those to Mary covering traditional, Catholic religion and those to Elizabeth addressing evangelical, reformed religion, showing that dedicators understood the differing religious views of the princesses. Dedicators were also aware that both princesses were highly educated and were prepared to contribute to their educations, with Elizabeth receiving dedications to two textbooks and Mary receiving three. Even though Mary and Elizabeth received preaccession dedications to similar types of books, the dedicators of those books perceived the princesses very differently. The difference in number of dedications to each princess, alone, suggests that Mary was perceived to be more important at court and have more patronage power than did her sister (Richards 2012, 194; Dowling 1986, 238). 
Dedications to the sisters before their accession to the throne demonstrate that Mary was regarded as an important figure, no matter her demoted status, while Elizabeth was often disregarded as a second daughter of the king, no matter her legal status.

As queen, Mary received twenty-five printed book dedications, while Elizabeth received fourteen in the first five years of her reign (Schutte 2015; Wood 2008). Each queen also received numerous manuscript dedications, most of which were given as New Year's gifts, as New Year's festivities were traditionally an occasion to give and receive gifts, thus providing the ideal opportunity to give the queen a present and receive something in return, such as a gift or patronage. ${ }^{1}$ The New Year's gift exchange allowed an opportunity for miscellaneous people with no connection to court to provide the monarch with a gift, a position many of the dedicators would have found themselves in (Heal 2014, 94). ${ }^{2}$ For Mary, her queen-era dedications followed three main themes: obedience, classical literature and philosophy, and the return of the true religion, while almost always reinforcing Mary's virtue, and the subject matter of the books themselves often followed the same four ideas (Schutte 2015,49 ). The dedications to Elizabeth in the first five years that she was queen mostly addressed religion (of varying sorts), virtue, and the increase of knowledge, whether classical or modern anatomy or architecture.

For both queens, dedications often followed a similar rhetorical pattern. A dedication would begin with praise, either of the queen's virtue, lineage, or education, would then briefly explain the text which the dedication accompanied, would explain why the text reminded the dedicator of that specific queen, and would end in some type of prayer or wish for prosperity and a long reign. For example, John Veron noted Elizabeth's "princelye goodness," as he

\footnotetext{
${ }^{1}$ Manuscripts dedicated to Queen Elizabeth include British Library (BL), Royal MS $5 \mathrm{E}$ XVII; BL, Royal MS 2 D II; BL, Royal MS 12 A XXX, Wellcome Library MS 136. For a detailed discussion of manuscripts dedicated to Queen Mary, see Schutte $(2015,81-$ 101). According to Natalie Zemon Davis, the act of gift-giving required action by both giver and receiver; a New Year's gift not only honored the monarch but implied desire for patronage during the upcoming year (2000, 14 and 24). Felicity Heal has recently published on gift-giving in England. See especially her chapter "The Politics of Gift-Exchange under the Tudors" (2014, 87-120).

2 Heal suggests that Elizabeth had "enthusiasm for elegantly bound volumes, alongside the more obvious clothes and jewels" (2014, 97-98).
} 
was a stranger to her and presented his book as a blind offering to her (Veron, 1561, C.iii.r). Once Veron offered Elizabeth such praise, he was then able to explain his text and thoughts on predestination to ask Elizabeth to accept his text and pass it on so that it could become known to her subjects. Veron, like so many other dedicators to other sixteenth-century English royal ladies, specifically Lady Margaret Beaufort and the six consorts of Henry VIII, also implied how a royal connection made a text more valuable, sellable, and authoritative (Schutte 2015, 7). ${ }^{3}$

\section{Counsel}

Unlike when Mary and Elizabeth were princesses, dedications to the queens were more forthcoming in offering counsel, as it was wellknown that monarchs needed good counsel so as to make good decisions (Schutte forthc.; Hoak 1995, 4). ${ }^{4}$ However, it was more critical to offer counsel to Mary and Elizabeth because it was not known how either woman would handle her power and perform her duties. Therefore, dedicators often noted that it was their bound duty to write these books and present them to the queen. Beyond duty, in order not to seem belligerent towards the queens, dedicators often couched their texts as being done for the good of the queen's subjects or for the good of the commonweal; their books were necessary to teach English people a lesson or remind them of their responsibilities. Yet, this professed duty was much more often a flattering way of saying that the dedicator was trying to offer some type of advice to the queen.

\footnotetext{
${ }^{3}$ Wood asserts that a "dedication to the Queen provided a cloak of legitimacy whether she knew the author or not" $(2008,6)$.

${ }^{4}$ Counsel is currently a popular historiographic trend that has mostly been done for kings, but studies on counsel to queens continue to be forthcoming. For an example of feminizing counsel within Tudor literature, see Ward (2013). Ward is particularly interested in how feminized counsel was portrayed on stage and suggests that the "rhetoric of counsel" changed with the reigns of Mary and Elizabeth, and on place that this is most evident is within tragedy plays, in which queens were often presented as counselors. Another recent study on late medieval counsel addresses mirrors for princes and their veiled political commentary (Ferster 1996). Joanne Paul and Helen Matheson-Pollock also have a forthcoming edited collection on queenship and counsel (2017).
} 
Mostly, dedicators counselled Mary in religion, specifically, to listen to her religious advisors who recommended the return of the Church of England back to Catholicism (Schutte 2015, 68-80). She was actually counselled by dedicators to follow the advice of her political council, implying that male dedicators thought that a queen regnant had to listen to male councilors because the nature of female rule was not yet fully established. Henry Parker, Lord Morley, longtime friend and supporter of Mary, wrote that she should follow "the wise counsel of the vnculpable, vertuous Cardinall, your cosyn," in matters of religion. ${ }^{5}$

Elizabeth was also counselled in religious matters, yet her dedicators often sought to steer her away from Catholicism, such as the dedication accompanying a Bible printed in Geneva by Elizabeth's "humble subiects of the English Churche at Geneua" (Bible, 1560, f. ii.r.). These (presumably) men counselled Elizabeth to be wary of her enemies (papists and prelates) and offered her the scriptures in English so that she did not have to listen to the false words of papists. Elizabeth, too, was counselled to choose good friends and counsellors as kings and queens attracted false friends. ${ }^{6}$ She was warned that the biblical King David encountered many enemies, so like David, she should rely on God to help her choose good counsellors (Boke of Psalmes 1559, *iiii,v.). ${ }^{7}$ Laurence Humphrey also advised Elizabeth take the advice of her counsellors, but at the same time warned her to get rid of treacherous nobles.

While all monarchs were expected to have counsellors and listen to their advice, these dedications show that dedicators to both Mary and Elizabeth thought that as queens they were more susceptible to taking bad advice and needed to surround themselves with qualified (male) counsellors. Thus, dedicators used dedications to surreptitiously offer their ideas to the queens, similarly to how panegyric verses also had the double meaning of providing council (Walsham 2003, 147).

\footnotetext{
${ }^{5}$ The dedications to all of Morley's manuscripts have been reprinted in Wright (1953, 183).
${ }^{6}$ Tara Wood suggests that dedicators "subtly" advanced "ideas of the commonwealth, and the duties of the citizen, usually while emphasizing that the she must rely on her advisors as responsible men" $(2008,175)$. The typo is in Wood's dissertation.

${ }^{7}$ This dedication is missing at least the first page on EEBO, so it is not possible to determine the exact dedicator.
} 


\section{Religion}

Again as in the pre-accession dedications, religion was the most common theme in the dedications to Queens Mary and Elizabeth. Dedicators addressing both Mary and Elizabeth sought to influence and support religious change. Dedications to Mary exhorted her to return England to the true religion of Catholicism, while those to Elizabeth were much more varied in scope (Schutte 2015, 68-80). Elizabeth received dedications advocating predestination, religious reform, and even Catholicism. This variation in dedications to Elizabeth shows the desire for religious reform by both Catholics and Protestants at the outset of Elizabeth's reign. Elizabeth's religious settlement, while re-instating stateled religion, was much more moderate in nature than her brother's settlement had been, thereby allowing all religious sects to attempt to counsel Elizabeth how to set up the newly re-established Church of England. When Mary became queen, there was no such confusion, as it was wellknown that she desired a reconciliation with Catholicism.

One important similarity in the religious dedications directed to both queens was the way in which many dedicators suggested that each woman was placed on the throne through God's will. Mary became queen because God wanted to return England to Catholicism, while Elizabeth became queen by divine will to purify the Church of England. This similarity is significant, because scholars have previously emphasized the providential nature of literary sources associated with Elizabeth, but have not made the same connections for Mary. ${ }^{8}$

For Elizabeth, several of her early dedications mentioned that she was placed on the throne by divine providence because of her Protestantism. In 1559, the dedication by anonymous subjects residing in Geneva accompanying The Boke of Psalmes noted that "God had not lesse miraculously p[re]ferred you to that excellent dignitie [...] aboue all mens expectations," meaning that God incredibly made her queen after having to endure the reign of Mary (Boke of Psalmes, 1559, *.iii.r). In another text printed shortly after Elizabeth's accession, Joannes Ferrarius claimed that "it hath pleased the greate Lord [...] to enstall your highnesse by his diuine

\footnotetext{
${ }^{8}$ Susan Doran has written about how John Foxe's dedication to Elizabeth heralded in peace, prosperity, and reform $(2003,172)$.
} 
prouidence, in the Roialle throne of maiestie" (1559, C.ii.r). Similarly, John Foxe argued that God gave England Elizabeth because so much persecution was done before she was queen (1563).

Yet Mary's propagandists also saw her as placed on the throne through divine intervention after the religiously oppressive reign of her brother, Edward. Richard Smith noted that Mary was "preserved" for many years under her enemies but with God's "singuler help" Mary was able to take the throne (Smith 1554, C.ii.vC.iii.r). Mary had neither riches nor political power, but was able to overthrow her enemies with the help of God. Likewise, Robert Recorde argued that "Godde in despite of cancred malyce and of frowninge fortune, dyd exaulte your maiestie to that throne royall, which iustice dyd belonge vnto your highness" (Recorde 1556, a.ii.r). The rhetorical strategy of divine favor, then, was first used with Mary but was taken over by Elizabeth's dedicators, and later used within the myth that England was favored by God for its Protestantism.

Images of powerful biblical women were also first used by Marian propagandists to describe Mary, but were later taken over by Elizabethan propagandists. ${ }^{9}$ At Mary's coronation, she was compared with Judith and Judith's defeat over Holofernes. ${ }^{10}$ Holofernes was probably meant to be representative of Edward and his religious settlement that Mary defeated within only a few months of becoming queen. These same biblical females were also compared to Mary in book dedications. In his dedication, John Angell wrote that England had recently been full of people who interpreted Scripture for themselves, "Tyll suche tyme that it pleased God of his infinite mercy, to sende us a newe Judith, by whose godlines the trewe light and knowledge of Goddes worde is nowe by her brought agayne" (Angell 1555, A.ii.v-A.iii.r). These female biblical figures were then "commandeered" by authors to represent Elizabeth because the connection between royal lady and biblical lady was so dominant (Kewes 2010, 48). Laurence Humphrey noted that though

\footnotetext{
${ }^{9}$ It is now recognized that Elizabeth and her propagandists borrowed much for Mary, and in some instances had to overtake the images used by Mary because they were so powerful (Kewes 2010, 47, 58-59; Wood 2008, 126).

${ }^{10}$ Duncan suggests that Holofernes was meant to represent Northumberland, whom Mary defeated in order to take the throne from Lady Jane Grey (2012, 161; King 1989, 218-19).
} 
Elizabeth was a woman, God preferred her and made her queen, just as He preserved several biblical women, such as Judith and Deborah (Humphrey 1563, B.i.r). ${ }^{11}$

\section{The Queen as King}

Dedications to Mary and Elizabeth share one other surprising image: the queen as king. Carole Levin has convincingly argued that Elizabeth considered herself to be both queen and king and that many authors represented her as such (Levin 2013, 131 and 148). Yet Marian scholars have recently shown that Mary, too, exhibited kingly characteristics, such as at her coronation and when she touched for scrofula (Richards 2008, 122, 137, 242; Duncan 2012, 27). Dedicators also contributed to Mary's image as king, more so than has previously been recognized (Schutte 2015, 56-57). In his dedication to his text on Wyatt's Rebellion, John Proctor twice noted that traitors "who through hatred to their prince or countrey shall either of their own malicious disposition be stirred" (1554-1555, a.iii.r) and "or of malice to their prince wyll entre into that horrible crime of preuie conspiracie or open rebellion" (1554-1555, a.iii.r). Proctor used the term "prince" in the general context of a leader, reinforcing Mary's legitimate right to be the sovereign, even when participants in Wyatt's Rebellion thought otherwise. This is in drastic contrast with many of the other dedications received by Mary, and many of those received by Elizabeth, in which the dedicators referred to Mary as both queen and princess, perhaps suggesting less power than a prince might have had.

One other dedicator to Mary, James Cancellar, in his dedicatory epistle to another book on obedience, made a biblical reference to the Book of Deuteronomy and how in it the children of Israel were called to be obedient to God. Cancellar's full title mentioned that all subjects needed to be obedient to both the king and queen, but the dedication was only directed towards Mary. This is important because in the dedication Cancellar noted that subjects ought to be obedient to their "king and gouernor," especially those who served him and made their living by him (Cancellar 1553, A.ii.v). Cancellar

\footnotetext{
${ }^{11}$ Wood suggests that Humphrey used his dedication as a commentary on female rule, suggesting that Elizabeth should reform the church as her father and brother had done, but in a traditional female way $(2008,94)$.
} 
used the term "king" as it was the term used in Deuteronomy, however, Cancellar did not qualify the term in any way. Therefore, in making a dedication to Mary that argued for the duty of obedience to the king, or supreme leader, Cancellar implied that Mary was both queen and king, which is why she deserved complete obedience (Schutte 2015, 55). Dedications such as these, should be used in conjunction with emerging Marian studies of her image, both created by her and for her, and her strategies of rulership to get a more even-handed and accurate picture of Mary as queen and what she demonstrated for Elizabeth (Richards 2010, 31-46).

Dedications in the first five years of Elizabeth's reign did not refer to Elizabeth as king, but as princely. Like Proctor, dedicators did not consider Elizabeth to be King of England, but did understand her to be the prince and legitimate ruler of England. Peter Whitehorne, in his dedication to his translation of Niccolo Machiavelli's The arte of W arre, noted that he dedicated his book on war to Elizabeth because wartime preparations were "determined by the abritremente of Gouernours and Princes" (Machiavelli 1562, a.iii.v). Thomas Bloundeville dedicated his translation of Plutarch's Three morall treatises to Elizabeth because in these treatises Plutarch shows where "a Prince ought most texcell" (Plutarch 1561, A.ii.r). And, John Veron wrote to Elizabeth that she had "Princelye goodness" and a "princelye harte" (Veron 1561, C.iii.r-C.viii.v) while John Foxe wrote of Elizabeth's "princely benignitie" (1563, B.ii.v). As for Mary, these dedicators did not qualify their use of the term "prince," thereby acknowledging that Elizabeth was their ruler and giving way to the later images of Elizabeth as both king and queen. Only one dedicator truly faulted Elizabeth for her sex, and that was Laurance Humphrey, who several times over the course of his eighteen-page long dedication mentioned that Elizabeth lacked the power of a "manlye kynge," yet was a successful queen, although what she accomplished was through God's work and not her own (H umphrey 1563, A.ii.v).

However, the anonymous members of the English church in Geneva made a much stronger case for Elizabeth as both king and queen of England. In their dedication, they compared Elizabeth to the biblical King David, as both she and David withstood "perils and persecutions" before attaining the throne, referencing Elizabeth's confinement in the Tower during her sister's reign (Boke of Psalmes 
1559, *ii.v). Likewise, the dedication frequently repeats that God put both her and David on the throne, so she should find comfort in God and that it is her duty to support His true (reformed) religion. This comparison of Elizabeth and David was not done because the members of the English church in Geneva regarded Elizabeth as King of England, but because David was a providential monarch, like Elizabeth, so he was a biblical figure from whom Elizabeth could learn how to govern (Doran 2010, 96; Walsham 2003, 147). However, it is through comparisons such as this that Elizabeth was able to fashion her image as both king and queen. But it is important to note that before Elizabeth, Mary had similar implications made of her status, thereby revealing that having a female monarch regarded as both king and queen was not novel with Elizabeth, only made clearer as Elizabeth's reign was significantly longer and Elizabeth ultimately chose not to marry.

\section{Statecraft}

Tellingly, there are some significant differences between the book dedications to Mary and Elizabeth. The most notable difference is how dedicators treated statecraft. Tara Wood noted that of the 183 printed dedications that Elizabeth received, almost all explored religion in some way, while others accompanied texts on "shorthand to science and statecraft" $(2008,6)$. Peter Whitehorne suggested in his dedication to The arte of warre that it was important to know of arms and defense because no real $m$ was free from using them. It was his duty to offer a text that would increase knowledge on the subject of war. He specifically dedicated his translation to Elizabeth because not only would her name give special authority to the text, but also "for the better defence of your highnesse," her subjects, and the realm (Machiavelli 1562, a.iii.r). As a woman Elizabeth would not have been expected to have been educated in military strategy, yet dedicators such as Whitehorne were pragmatic enough to realize that Elizabeth would need some sort of guidance should the need arise. $^{12}$

\footnotetext{
${ }^{12}$ Wood suggests that Whitehorne's dedication shows male anxiety over having a queen regnant, as Whitehorne suggests that educating male subjects in war will increase virility $(2008,189-90)$.
} 
Mary, on the other hand, did not receive any books or dedications on statecraft. No author gave Mary advice how to act politically as queen, instead mentioning in their dedications that Mary was surrounded by good council. For example, Robert Recorde wrote that "God not only hath endewed [Mary] with excellent knowledge, but also hath ayded with such prudent Councellars" (1556, a.ii.v). Elizabeth had qualified councilors as well, but dedications such as Whitehorne's suggest that English people accepted Elizabeth's role as head of the political realm more so than was accepted for Mary. I argue that dedicators to Mary did not address statecraft because it was assumed that politics was outside of Mary's purview even though she was queen; Mary's councilors would make political decisions for her. Even the books that Mary received in the aftermath of political rebellions did not address that Mary needed to know how to take charge with arms, but instead offered her advice of how to better command the obedience of her people (Cancellar 1553; Proctor 1554-1555). After Mary's marriage to Philip II of Spain, dedicators always mentioned both Mary's Engl ish and Spanish titles, but almost never mentioned Philip by name or even at all. The couple only received five joint dedications (Schutte $2015,105)$. This suggests that dedicators did acknowledge that Mary had superior authority in the realm, even over the king, but that dedicators were still not quite ready for a woman to rule politically (Schutte 2015, 103-15). By the accession of Elizabeth it was recognized that a female ruler did at least need some political knowledge, but it was still expected that male councilors would be making most of the political decisions.

\section{Conclusion}

This essay has briefly compared printed book dedications to Mary and Elizabeth Tudor before each woman became queen and during their first five (or only five) years as queens. As queen, Mary received twenty-five printed book dedications, while Elizabeth received only fourteen during her first five years as queen, and each woman also received several manuscript dedications. Those dedications had many similarities. They often followed the same rhetorical patterns, acknowledged that connection to a royal patron would lead to greater sales and influence of their books, and offered some type of covert advice to the queens under the guise of flattery. 
Even though religious policy was not typically an area under a woman's purview, the amount of dedications to both women dealing with religion suggests that dedicators were more comfortable with their queens having an impact on religion more so than statecraft.

Yet, dedications to the Tudor sisters as queens show that these two women were perceived more commonly than has previously been recognized. Both received veiled counsel, both were expected to have more power over religion than statecraft, and both were thought to need guidance on how to maintain the obedience of their people. This essay suggests that for all of their differences as princesses, the book dedications to Mary and Elizabeth as queens are incredibly similar. By exploring these book dedications, it becomes evident that dedications were central to contemporary perceptions of what authors and translators thought Mary and Elizabeth would be interested in reading and passing along to their subjects al ong with what dedications thought the sister queens should be reading so as to be persuaded in different directions.

\section{References}

Manuscripts

London, British Library (BL), Royal MS5E XVII

London, BL, Royal MS2 D II

London, BL, Royal MS 12 A XXX

London, Wellcome Library, MS 136

\section{Printed primary sources}

Angell, John. 1555. The agrement of the holye fathers, and D octors of the churche, vpon the cheifest articles of Christian religioun as appeareth on the nexte syde folowinge, very necessary for all curates. London: William Harford. STC 634.

Bible and Holy Scriptures conteyned in the Olde and Newe Testament, The. Translated by William Whittingham. Geneva: Rouland Hall, 1560. STC 2093.

Boke of Psalmes where in are conteined praiers, meditations, praises \& thankesgiuing to God for his benefites toward his church, The. Geneva: Rouland Hall, 1559. STC 2384.

Cancellar, James. 1553. The Pathe of 0 bedience, righte necessarye for all the king and Quenes maiesties louing Subiectes, to reade, learne, and use their due 
obediences, to the hyghe powers accordynge to thys godly treatise compiled by James Cancellar, one of the Quenes M aiesties moste honourable Chapell. London: John Wayland. STC 4564.

Ferrarius, Johannes, Touchynge the good orderynge of a common weale wherein aswell magistrates, as priuate persones, bee put in remembraunce of their dueties, not as the philosophers in their vaine tradicions haue deuised, but according to the godlie institutions and sounde doctrine of christianitie. Englished by william Bauande. London: John Kingston, 1559. STC 10831.

Foxe, John. 1563. Actes and monuments of these latter and perillous dayes touching matters of the Church, wherein ar comprehended and decribed the great persecutions [and] horrible troubles, that haue been wrought and practiced by the Romishe prelates, speciallye in this realme of England and Scotlande, from the yeare of our Lorde a thousand, vnto the tyme now present. London: John Day. STC 11222.

Hannapes, Nicholas de. 1561. The ensamples of vertue and vice, gathered oute of holye scripture. Translated by Thomas Paynell. London: J. Tisdale. STC 12742.

Humphrey, Laurence. 1563. The nobles or of nobilitye. London: Thomas Marsh. STC 13964.

Machiavelli, Niccolo. 1562. The arte of warre, written first in Italia[n] by $\mathrm{Nicholas} \mathrm{M}$ achiauell, and set forthe in Englishe by Peter Whitehorne Translated by Peter Whitehorne. London: John Kingston. STC 17164.

Plutarch. 1561. Three morall treatises no lesse pleasaunt than necessary for all men to reade, wher of the one is called the learned prince, the other the fruites of foes, the thyrde the port of rest. London: William Seres. STC 20063.5.

Proctor, John. 1554-1555. The historie of wyates rebellion, with the order and maner of resisting the same, wherunto in the en de is added an earnest conference with the degenerate and sedicious rebelles for the serche of the cause of their daily disorder. London: John Caly. STC 20407.

Recorde, Robert. 1556. The castle of knowledge. London: Reginald Wolfe. STC 20796.

Smith, Richard. 1554. A bouclier of the catholike fayth of Christes church, conteynyng diuers matters now of late called into controuersy, by the newe gospellers. London: Richard Tottell. STC 22816.

Veron, John. 1561. A fruteful treatise of predestination, and of the deuyne prouidence of god as far forth as the holy scriptures and word of god shal lead vs. London: John Tisdale. STC 24680.

\section{Secondary sources}

Baranda Leturio, Nieves. 2011. “Women's Reading Habits: Book Dedications to Female Patrons in Early Modern Spain." In Women's Literacy in Early 
Schutte

Modern Spain and the New World, edited by Anne J. Cruz and Rosilie Hernández, 19-39. Surrey: Ashgate.

Brogan, Stephen. 2015. The Royal Touch in Early Modern England: Politics,

M edicine, and Sin. Suffolk: Boydell \& Brewer.

Buchte, John. 2004. "Book Dedications and the Death of a Patron: The Memorial Engraving in Chapman's Homer." Book H istory 7: 1-29.

- - - 2008. "'To the Most High and Excellent Prince': Dedicating Books to Henry, Prince of Wales." In Prince H enry R evived: I mage and Exemplarity in Early Modern England, edited by Timothy V. Wilks, 104-33. London: Holberton.

Burke, Mary E., Jane Donawerth, Linda L. Dove, and Karen Nelson, eds. 2000. W omen, W riting, and the Reproduction of Culture in Tudor and Stuart Britain. Syracuse, NY: Syracuse University Press.

Crawford, Julia. 2014. M ediatrix: Women, Politics, and Literary Production in Early M odern England. Oxford: Oxford University Press.

Davis, Natalie Zemon. 2000. The Gift in Sixteenth-Century France. Madison: The University of Wisconsin Press.

Doran, Susan. 2003. "Virginity, Divinity and Power: The Portraits of Elizabeth I." In The M yth of Elizabeth, edited by Susan Doran and Thomas S. Freeman, 171-99. New York: Palgrave Macmillan.

_- - 2010. "Elizabeth I: An Old Testament King." In Tudor Q ueenship: The Reigns of $M$ ary and Elizabeth, edited by Alice Hunt and Anne Whitelock, 95-110. New York: Palgrave Macmillan.

Dowling, Maria. 1986. H umanism in the A ge of Henry V III. Kent: Croom Helm, Ltd.

Duncan, Sarah. 2011. "The Two Virgin Queens: Embodying Queenship in the Reigns of Mary I and Elizabeth I." In Elizabeth I and the "Sovereign Arts": Essays in History, Literature, and Culture, edited by Donald Stump, Linda Shenk, and Carole Levin, 29-52. Tempe: Arizona Center for Medieval and Renaissance Studies.

_-_. 2012. M ary I: Gender, Power, and Ceremony in the Reign of England's First Q ueen. N ew York: Palgrave Macmillan.

Erler, Mary C. 2002. Women, Reading, and Piety in Late M edieval England. Cambridge: Cambridge University Press.

Ferster, Judith. 1996. Fictions of A dvice: The Literature and Politics of Counsel in Late M edieval England. Philadelphia: University of Pennsylvania Press.

Frye, Susan. 2010. Pens and Needles: Women's Textualities in Early M odern England. Philadelphia: University of Pennsylvania Press. 
Goldsmith, Elizabeth C. and Dena Goodman. 1995. Going Public: Women and Publishing in Early M odern France. Ithaca, NY: Cornell University Press.

Guardiola-Griffiths, Cristina. 2011. Legitimizing the Queen: Propaganda and Ideology in the Reign of I sabel I of Castile. Lewisburg: Bucknell University Press.

Heal, Felicity. 2014. The Power of Gifts: Gift-exchange in Early M odern England. Oxford: Oxford University Press.

Hannay, Margaret P. 1985. Silent But for the Word: Tudor Women as Patrons, Translators, and Writers of Religious Works. Kent, $\mathrm{OH}$ : Kent State University Press.

Hoak, Dale. 1995. Tudor Political Culture. Cambridge: Cambridge University Press.

Hull, Susanne W. 1982. Chaste, Silent \& O bedient: English Books for Women, 1475-1640. San Marino, CA : Huntington Library Press.

Hunt, Alice and Anna Whitelock, eds. 2010. Tudor Queenship: The Reigns of $M$ ary and Elizabeth. New York: Palgrave Macmillan.

Kewes, Paulina. 2010. "Godly Queens: The Royal Iconographies of Mary and Elizabeth." In Tudor Q ueenship: The Reigns of M ary and Elizabeth, edited by Alice Hunt and A nne Whitel ock, 47-62. N ew York: Palgrave Macmillan.

King, John. 1989. Tudor Royal Iconography: Literature and Art in an Age of Religious Crisis. Princeton: Princeton University Press.

Levin, Carole. 2013. The H eart and Stomach of a King: Elizabeth I and the Politics of Sex and Power. $2^{\text {nd }}$ ed. Philadelphia: University of Pennsylvania Press.

M clntosh, J.L. 2009. From H eads of $\mathrm{H}$ ousehold to $\mathrm{H}$ eads of State: The Preaccession H ouseholds of M ary and Elizabeth Tudor, 1516 to 1558. N ew York: Columbia University Press.

Moore, Helen. 2011. "Gathering Fruit: The 'Profitable' Translations of Thomas Paynell." In Tudor Translation, edited by Fred Shurink, 39-57. New York: Palgrave Macmillan.

Paul, Joanne and Helen Matheson-Pollock. 2017. Q ueenship and Counsel in the Early M odern World. New York: Palgrave Macmillan.

Pollnitz, Aysha. 2015. Princely Education in Early M odern Britain. Cambridge: Cambridge University Press.

Richards, Judith M. 2008. M ary Tudor. London: Routledge.

- - 2010. "Examples and Admonitions: What Mary Demonstrated for Elizabeth." In Tudor Q ueenship: The Reigns of M ary and Elizabeth, edited by Alice Hunt and A nna Whitelock, 31-46. New York: Pal grave Macmillan.

_-_. 2012. Elizabeth I. London: Routledge. 
Schutte

Schutte, Valerie. 2015. M ary I and the Art of Book Dedications: Royal Women, Power, and Persuasion. New York: Palgrave Macmillan.

-_- 2016. "Under the Influence: The Impact of Queenly Book Dedications on Princess Mary." In The Birth of a Queen: Essays on the Q uincentenary of M ary I, edited by Sarah Duncan and Valerie Schutte, 3148. New York: Palgrave Macmillan.

-_- (forthcoming). "Perceptions of Princesses: Pre-accession Book Dedications to Mary and Elizabeth Tudor." In U nexpected H eirs in Early Modern Europe: Potential Kings and Queens, edited by Valerie Schutte. New York: Palgrave Macmillan.

Smith, Helen. 2012. "Grossly M aterial Things": Women and Book Production in Early M odern England. Oxford: Oxford University Press.

Walsham, Alexandra. 2003. "'A very Deborah?' The Myth of Elizabeth I as a Providential Monarch." In The M yth of Elizabeth, edited by Susan Doran and Thomas S. Freeman, 143-68. N ew York: Palgrave Macmillan.

Ward, Allyna E. 2013. Women and Tudor Tragedy: Feminizing Counsel and Representing Gender. Madison: Fairleigh Dickenson University Press.

Wood, Tara. 2008. "'To the most godlye, virtuos, and myghtye Princess Elizabeth': Identity and Gender in the Dedications to Elizabeth I." PhD diss., A rizona State University.

Wright, Herbert G. 1943. Forty-six Lives. London: Early English Text Society.

How to cite this article:

Schutte, Valerie. "Perceptions of sister queens: A comparison of printed book dedications to Mary and Elizabeth Tudor." SED ERI 27 (2017): 149-66.

A uthor's contact: veschutte@gmail.com

Postal address: Independent Scholar - Pittsburgh, PA, USA

Submission: 19/ 10/ 2016

A cceptance: 15/ 11/ 2016 